\title{
Analisis Hubungan Pengetahuan dan Persepsi Pasien dengan Partisipasi Pasien di Instalasi Paviliun Ambun Pagi RSUP DR. M. Djamil Padang Ditinjau dari Aspek Hukum Keselamatan
}

\section{Pasien}

Anshar Bonas Silfa ${ }^{1}$, Hardisman $^{2}$, Aumas Pabuti $^{3}$

\begin{abstract}
Abstrak
Pasien bisa memainkan peranan penting dalam peningkatan keselamatan pasien dengan terlibat aktif dalam proses perawatan mereka. Partisipasi pasien dipandang sebagai hak hukum pasien serta standar emas sistem pelayanan kesehatan internasional. Tujuan penelitian ini adalah mengetahui hubungan pengetahuan dan persepsi pasien tentang aspek hukum keselamatan pasien dengan partisipasi pasien dalam keselamatan pasien di Instalasi Paviliun Ambun Pagi RSUP Dr. M. Djamil Padang. Ini adalah penelitian kuantitatif dengan pendekatan cross sectional study. Sampel ditentukan dengan cara systematic random sampling. Data dikumpulkan selama bulan Maret tahun 2016. Hasil penelitian terhadap 75 orang responden menunjukkan bahwa sebagian besar memiliki pengetahuan kurang (42 [56.00\%]) dan persepsi negatif (49 [65.33\%]), serta sebagian besar memiliki partisipasi yang rendah (46 $[61,33 \%])$. Ada hubungan antara pengetahuan $(p=0,024)$ dan persepsi pasien $(p=0,007)$ tentang aspek hukum keselamatan pasien dengan partisipasi pasien dalam keselamatan pasien. Berdasarkan hasil penelitian dapat disimpulkan bahwa pengetahuan dan persepsi pasien tentang aspek hukum dalam keselamatan pasien memiliki hubungan dengan partisipasi pasien dalam keselamatan pasien. Perlu ditingkatkan edukasi dan informasi tentang hak pasien dalam keselamatan pasien bagi pasien dan keluarga, guna mendorong peningkatan partisipasi pasien.
\end{abstract}

Kata kunci: keselamatan pasien, aspek hukum keselamatan pasien, pengetahuan, persepsi, partisipasi pasien

\begin{abstract}
Patients can play an important role in improving patient safety by becoming actively involved in their health care. Patient participation is regarded as a legal right of the patient as well as an international gold standard for healthcare systems. The objective of this study was to determine the relationship between patient knowledge as well as perception regarding legal aspects of patient safety and patient participation in patient safety program, in Ambun Pagi pavilion unit of Dr. M. Djamil Central Hospital of Padang. It's a quantitative research using cross sectional study approach. Sampling was conducted by systematic random sampling. Data was collected during March 2016. Results of 75 respondents found the most had less knowledge (42 [56.00\%]) and negative perceptions (49 [65.33\%]), and the most had less participation (46 [61,33\%]) in patient safety program. Furthermore, it found a significant relationship between patients knowledge $(p=0.024)$ as well as perception $(p=0.007)$ regarding legal aspects of patient safety and patient participations in patient safety program. This study identified patient knowledge and perception regarding legal aspects patient safety associated with patient participation in patient safety program. Therefore, it's important to support patients and families with adequate education and information about patients rights in patient safety to encourage patient participation in patient safety program.
\end{abstract}

Keywords: patient safety, legal aspects of patient safety, knowledge, perception, patient participation 
Affiliasi penulis: 1. Prodi S2 Kesehatan Masyarakat Kajian Fakultas Kedokteran Universitas Andalas Padang (FK Unand), 2. Bagian IImu Kesehatan Anak FK Unand, 3. Bagian IImu Kesehatan Anak FK Unand/RSUP DR. M. Djamil Padang

Korespondensi: Anshar Bonas Silfa, Email:

ansharcaniago@gmail.com, Telp: 08126650869

\section{PENDAHULUAN}

Keselamatan pasien dalam pelayanan kesehatan adalah hak pasien. Hak atas keselamatan merupakan titik kunci dalam pelaksanaan hak atas kesehatan. ${ }^{1}$ Berhubung hak itu selalu dikaitkan dengan hukum bahkan sulit dipisahkan antara hak dengan hukum, maka tidak mengherankan dalam hukum Eropa Kontinental istilah hak disamakan dengan hukum, yaitu ius (Latin), droit (Perancis), dan recht (Belanda). Keberadaan hukum dan deklarasi tentang hak pasien ini belum sepenuhnya menjamin pelayanan kesehatan akan lebih aman, akan tetapi dapat meningkatkan pemberdayaan pasien, dengan menempatkan mereka pada posisi yang lebih baik dalam mengelola pelayanan kesehatan dan kesehatan mereka sendiri, serta berpartisipasi dalam upaya peningkatan keselamatan.

Institute of Medicine (IOM) mendefinisikan keselamatan pasien sebagai "bebas dari cedera aksidental". ${ }^{2}$ Menurut WHO, keselamatan pasien adalah tidak terjadinya bahaya yang dapat dicegah pada pasien selama proses pelayanan kesehatan. ${ }^{3}$ Tak dipungkiri bahwa pada rumah sakit yang memiliki anggaran cukup atau yang berteknologi tinggi sekalipun masih terjadi Insiden Keselamatan Pasien (IKP), sehingga partisipasi pasien dalam perawatan mereka sangat diharapkan agar dapat mengurangi risiko kesalahan dalam pelayanan kesehatan. Saat ini partisipasi pasien telah dipandang sebagai hak hukum pasien serta standar emas sistem pelayanan kesehatan internasional. ${ }^{4}$

Di negara Indonesia, hak atas kesehatan merupakan hak asasi manusia sebagai salah satu unsur kesejahteraan yang harus diwujudkan sesuai dengan cita-cita bangsa Indonesia yang tertuang dalam Pancasila dan Undang-Undang Dasar Negara Republik Indonesia Tahun 1945. Hak-hak atas keselamatan dalam pelayanan kesehatan dilindungi oleh negara melalui sejumlah peraturan perundangundangan. Salah satunya adalah Undang-Undang RI
Nomor 44 tahun 2009 tentang Rumah Sakit ayat 1 yang mengisyaratkan bahwa: "Setiap rumah sakit mempunyai kewajiban memberi pelayanan kesehatan yang aman, bermutu, antidiskriminasi dan efektif dengan mengutamakan kepentingan pasien sesuai dengan standar pelayanan Rumah Sakit" ${ }^{5}$ Pada pasal 32 UU Nomor 44 tahun 2009 juga terdapat 18 butir hak-hak pasien dan pada pasal 43 dinyatakan bahwa "Rumah Sakit wajib menerapkan standar keselamatan pasien", 5 sehingga sebagai wujud pelaksanakan ketentuan pasal 43 ini ditetapkankanlah Peraturan Menteri Kesehatan RI Nomor 1691/MENKES/ PER/ VIII/ 2011 tentang Keselamatan Pasien Rumah Sakit. ${ }^{6}$ Dalam peraturan ini terdapat standar rumah sakit harus mendidik pasien dan keluarganya tentang kewajiban dan tanggung jawab pasien dalam asuhan pasien, dengan kriteria bahwa keselamatan dalam pemberian pelayanan dapat ditingkatkan dengan keterlibatan pasien yang merupakan partner dalam proses pelayanan. ${ }^{4}$

Gerakan Keselamatan Pasien Rumah Sakit di Indonesia diawali dengan terbentuknya Komite Keselamatan Pasien Rumah Sakit/KKPRS oleh organisisasi PERSI (Perhimpunan Rumah Sakit Seluruh Indonesia) pada Juni 2005, diikuti dengan pencanangan Gerakan Keselamatan Pasien Rumah Sakit oleh Menteri Kesehatan Dr. Siti Fadillah Supari pada 21 Agustus 2005 dalam Seminar Nasional PERSI di Jakarta. ${ }^{7}$

Di RSUP DR. M. Djamil Padang, program Keselamatan Pasien Rumah Sakit telah dicanangkan sejak tahun 2012 dengan membentuk Tim Keselamatan Pasien Rumah Sakit dan Manajemen Risiko Klinis, dan mulai menerapkan sistem pelaporan keselamatan pasien, sehingga sampai pertengahan tahun 2015 dilaporkan bahwa telah terjadi Insiden Keselamatan Pasien (IKP) sebanyak 20 kali. $^{8}$ Selanjutnya guna mendukung program Keselamatan Pasien Rumah Sakit ini di RSUP DR. M. Djamil Padang, telah diterbitkan sejumlah kebijakan dan Standar Prosedur Operasional (SPO) terkait. Pada prosesnya ketersediaan sumber-sumber informasi tentang hak-hak pasien dalam keselamatan pasien sebagai sarana pendidikan bagi pasien dan keluarga masih belum optimal dan belum cukup mampu untuk mendorong peningkatan partisipasi pasien dalam 
keselamatan pasien. Media komunikasi audio, visual dan media tertulis yang tersebar di lingkungan RSUP Dr. M. Djamil Padang masih terbatas untuk diakses oleh pasien.

Berdasarkan fenomena di atas dan masih terbatasnya data mengenai partisipasi pasien di Indonesia, maka perlu diadakan penelitian lebih lanjut terhadap hubungan pengetahuan dan persepsi pasien dengan partipasi pasien dalam pelayanan kesehatannya di Instalasi Paviliun Ambun Pagi RSUP Dr. M. Djamil Padang, sebagai perwujudan hak pasien atas keselamatan dalam pelayanan kesehatan.

\section{METODE}

Penelitian ini merupakan penelitian deskriptif analitik dengan pendekatan cross sectional study. Variabel terdiri dari pengetahuan pasien tentang aspek hukum keselamatan pasien dan persepsi pasien tentang aspek hukum keselamatan pasien sebagai variabel bebas. Partisipasi pasien dalam keselamatan pasien sebagai variabel terikat. Ketiga variabel dinilai dalam satu kali pengukuran pada waktu yang bersamaan. Penelitian dilakukan di Instalasi Paviliun Ambun Pagi RSUP Dr. M. Djamil Padang. Waktu penelitian mulai dari 1 Maret 2016 sampai dengan 31 Maret 2016.

Populasi penelitian ini adalah pasien yang dirawat di Instalasi Paviliun Ambun Pagi RSUP Dr. M. Djamil Padang. Rerata jumlah pasien dalam 1 bulan selama tahun 2015 adalah 240 orang. Besar sampel dihitung menurut rumus Lemeshow et al. ${ }^{9}$ Berdasarkan perhitungan sampel, maka ditetapkan jumlah sampel sebanyak 75 orang. Teknik pengambilan sampel menggunakan metode Systematic Random Sampling, yakni metode pengambilan sampel dimana hanya sampel pertama saja yang dipilih secara acak, sedangkan unsur-unsur selanjutnya dipilih secara sistematis menurut suatu pola tertentu, ${ }^{10}$ dimana dalam penelitian ini digunakan interval 3.

\section{Kuesioner}

Instrumen yang digunakan adalah kuesioner berisi pertanyaan tertutup, responden hanya memilih salah satu alternatif jawaban yang dianggap sesuai.
Kuesioner terdiri dari: data demografi, kuesioner pengetahuan pasien, kuesioner persepsi pasien, dan kuesioner partisipasi pasien. Validitas isi instrumen penelitian didukung oleh teori- para ahli (expert judgement). Sedangkan untuk menentukan validitas konstruk dan realibilitas instrumen penelitian telah dilakukan uji coba penggunaan kuesioner pada 10 responden yang berasal dari salah satu unit perawatan kelas 1 di RSUP DR. M. Djamil Padang. Selanjutnya diperoleh validitas konstruk melalui uji Pearson Product-Moment Correlation Coeficient dan Realibilitas instrumen melalui uji Alpha Cronbach $(\alpha=0,985)$.

\section{Pengumpulan dan analisis data}

Proses pengumpulan data berlangsung dari tanggal 1 sampai dengan 31 Maret 2016 di Instalasi Paviliun Ambun Pagi RSUP DR. M. Djamil Padang melibatkan 75 orang subyek penelitian, terdiri dari pasien-pasien yang telah selesai menjalani masa perawatan. Pasien yang memenuhi kriteria sampel diberikan penjelasan tentang penelitian dan dimohon kesediaan mengisi kuesioner pada saat mengurus administrasi kepulangan dari rumah sakit. Pendistribusian kuesioner dibantu oleh beberapa orang asisten peneliti, yakni para kepala ruangan di Instalasi Paviliun Ambun Pagi RSUP DR. M. Djamil Padang.

Analisis data diawali dengan analisis univariat untuk mendeskripsikan karakteristik setiap variabel penelitian. Kemudian dilanjutkan dengan analisis bivariat untuk mengetahui hubungan antara pengetahuan dan persepsi pasien tentang aspek hukum keselamatan pasien sebagai variabel bebas dengan partisipasi pasien dalam keselamatan pasien sebagai variabel terikat. Dalam penelitian ini menggunakan uji statistik Chi-square yang sering digunakan untuk menganalisis hubungan antara dua data katagorik.

\section{HASIL}

Karakteristik subyek penelitian dapat dilihat pada Tabel 1, dimana sebagian besar (62,67\%) berjenis kelamin pria, sebagian besar pula $(53,33 \%)$ 
berada pada kelompok usia dewasa muda (18-40 tahun), dengan lebih dari separuh (56,00\%) subyek penelitian telah menempuh jenjang pendidikan Diploma/Sarjana. Pekerjaan subyek penelitian lebih dari separuh $(62,67 \%)$ wiraswasta/ dagang.

Pola pembiayaan perawatan kesehatan sebagian besar (49,33\%) subyek penelitian menggunakan Asuransi Kesehatan dari Badan Penyelenggara Jaminan Sosial (BPJS) dengan kenaikan kelas perawatan/ selisih tarif. Pada Tabel 1 juga terlihat sebagian besar (53,33\%) subyek penelitian telah memiliki pengalaman dirawat di RSUP Dr. M. Djamil Padang, hanya sebagian kecil (24,00\%) subyek penelitian yang memiliki pengalaman dirawat di RS lain.

Alasan memilih RSUP Dr. M. Djamil Padang sebagai fasilitas pelayanan kesehatan sebagian besar $(26,28 \%)$ subyek penelitian adalah fasilitas RS terkenal lengkap dan canggih, sebanding dengan sebagian besar $(26,28 \%)$ subyek penelitian yang memilih pernyataan diharuskan oleh aturan BPJS (rujukan berjenjang)

Sebagian besar (85,33\%) subyek penelitian telah memperoleh informasi tentang hak-hak pasien atas keselamatan dalam pelayanan kesehatan. Demikian pula sebagian besar (78,67\%) subyek penelitian telah memperoleh informasi tentang sasaran keselamatan pasien.

Tidak ada subyek penelitian yang menggunakan obat-obatan alternatif selama dalam perawatan di Instalasi Paviliun Ambun Pagi RSUP DR. M. Djamil Padang.

\section{Pengetahuan pasien}

Hasil penelitian di Instalasi Paviliun Ambun Pagi RSUP DR. M. Djamil Padang yang digambarkan pada Diagram 1 menunjukkan bahwa sebagian besar $(56,00 \%)$ subyek penelitian memiliki pengetahuan yang kurang tentang aspek hukum keselamatan pasien dalam kategori kurang.
Tabel 1. Karakteristik subyek penelitian

\begin{tabular}{|c|c|c|}
\hline Karakteristik Subyek Penelitian & f & $\%$ \\
\hline \multicolumn{3}{|l|}{ Jenis kelamin } \\
\hline Pria & 47 & 62,67 \\
\hline Wanita & 28 & 37,33 \\
\hline \multicolumn{3}{|l|}{ Umur } \\
\hline $18-40$ & 40 & 53,33 \\
\hline $41-60$ & 29 & 38,67 \\
\hline$>60$ & 6 & 8,00 \\
\hline \multicolumn{3}{|l|}{ Cara bayar } \\
\hline Umum & 15 & 20,00 \\
\hline BPJS standar & 19 & 25,33 \\
\hline BPJS Selisih tariff & 37 & 49,33 \\
\hline Asuransi Lain-lain & 0 & 0,00 \\
\hline Tanggungan Perusahaan/ IKS & 4 & 5,33 \\
\hline \multicolumn{3}{|l|}{ Alasan memilih RSUP DR. M. Djamil } \\
\hline \multicolumn{3}{|l|}{ Padang } \\
\hline Lokasi berdekatan dengan tempat & & 19,87 \\
\hline tinggal & 31 & \\
\hline Rumah Sakit ini terkenal dengan & & 17,95 \\
\hline Pelayanan Bermutu & 28 & \\
\hline Fasilitas terkenal lengkap dan & & 26,28 \\
\hline canggih & 41 & \\
\hline Rekomendasi dari teman/ & & 5,13 \\
\hline keluarga & 8 & \\
\hline Diharuskan oleh aturan BPJS & & 26,28 \\
\hline (rujukan berjenjang) & 41 & \\
\hline Pilihan terakhir/Tidak ada pilihan & & 4,49 \\
\hline lain & 7 & \\
\hline \multicolumn{3}{|l|}{ Apakah mendapatkan informasi } \\
\hline \multicolumn{3}{|l|}{ tentang hak-hak pasien atas } \\
\hline \multicolumn{3}{|l|}{ keselamatan dalam pelayanan } \\
\hline \multicolumn{3}{|l|}{ kesehatan } \\
\hline Ya & 64 & 85,33 \\
\hline Tidak & 11 & 14,67 \\
\hline \multicolumn{3}{|l|}{ Apakah mendapatkan informasi } \\
\hline \multicolumn{3}{|l|}{ tentang sasaran keselamatan pasien } \\
\hline Ya & 59 & 78,67 \\
\hline Tidak & 16 & 21,33 \\
\hline \multicolumn{3}{|l|}{$\begin{array}{l}\text { Apakah menggunakan obat-obatan } \\
\text { alternative }\end{array}$} \\
\hline $\mathrm{Ya}$ & 0 & 0,00 \\
\hline Tidak & 75 & 100,00 \\
\hline
\end{tabular}




\section{Persepsi pasien}

Persepsi pasien di Instalasi Paviliun Ambun Pagi RSUP DR. M. Djamil Padang sebagaimana hasil penelitian pada Diagram 2 menunjukkan bahwa sebagian besar $(65,33 \%)$ subyek penelitian memiliki persepsi yang negatif tentang aspek hukum keselamatan pasien.

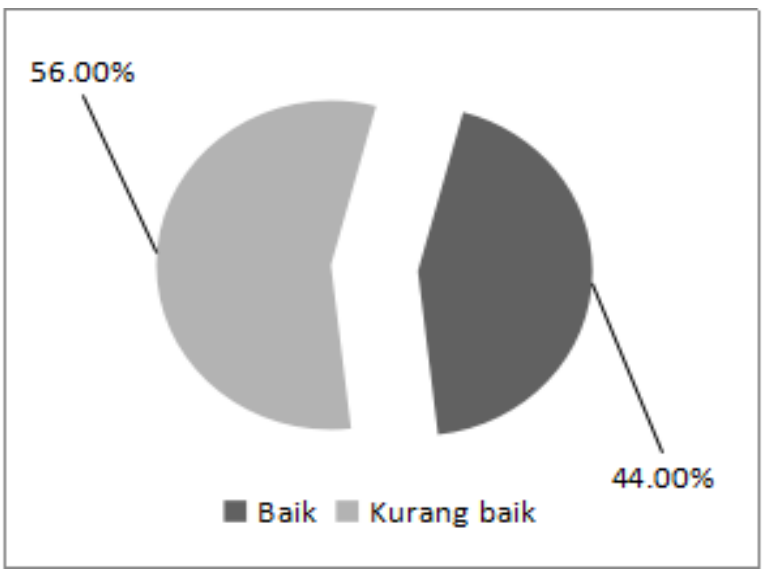

Diagram 1. Pengetahuan pasien tentang aspek hukum keselamatan pasien

\section{Partisipasi pasien}

Partisipasi pasien dalam keselamatan pasien di Instalasi Paviliun Ambun Pagi RSUP DR. M. Djamil Padang pada Diagram 3 menunjukkan bahwa sebagian besar $(61,33 \%)$ subyek penelitian memiliki partisipasi yang rendah dalam keselamatan pasien.

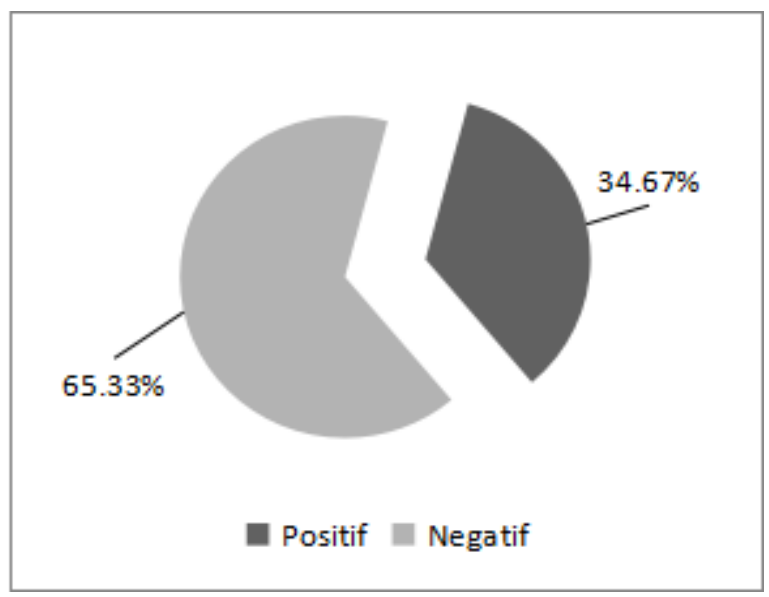

Diagram 2. Persepsi pasien tentang aspek hukum keselamatan pasien

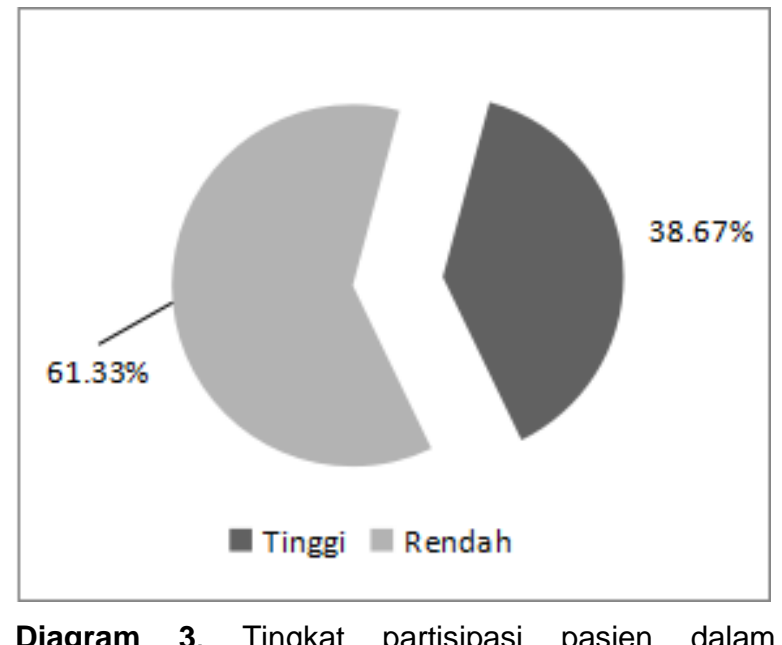

Diagram 3. Tingkat partisipasi pasien dalam keselamatan pasien

Hubungan pengetahuan pasien tentang aspek hukum keselamatan pasien dengan partisipasi pasien dalam keselamatan pasien

Pada Tabel 2 terlihat persentase tertinggi (73,81\%) partisipasi pasien dalam keselamatan pasien yang rendah terdapat pada pasien dengan pengetahuan tentang aspek hukum keselamatan pasien yang kurang. Secara statistik menggunakan uji Chi-Square terdapat hubungan antara pengetahuan pasien tentang aspek hukum keselamatan pasien dengan partisipasi pasien dalam keselamatan pasien di Instalasi Paviliun Ambun Pagi RSUP DR. M. Djamil Padang $(p=0,024)$.

Tabel 2. Hubungan pengetahuan pasien tentang aspek hukum keselamatan pasien dengan partisipasi pasien dalam keselamatan pasien di instalasi paviliun Ambun Pagi RSUP Dr. M. Djamil Padang

\begin{tabular}{|c|c|c|c|c|}
\hline \multirow{3}{*}{$\begin{array}{c}\text { Pengetahuan } \\
\text { Pasien }\end{array}$} & \multicolumn{3}{|c|}{ Partisipasi Pasien } & \multirow{3}{*}{$\mathbf{p}$} \\
\hline & Tinggi & Rendah & Jumlah & \\
\hline & $\%$ & $\%$ & $\%$ & \\
\hline Baik & 1854,55 & 1545,45 & 33100 & 0,024 \\
\hline Kurang Baik & 1126,19 & 3173,81 & 42100 & \\
\hline Jumlah & 2938,67 & $46 \quad 61,33$ & 75100 & \\
\hline
\end{tabular}


Hubungan persepsi pasien tentang aspek hukum keselamatan pasien dan partisipasi pasien dalam keselamatan pasien

Pada Tabel 3 terlihat persentase tertinggi $(73,47 \%)$ partisipasi pasien dalam keselamatan pasien yang rendah terdapat pada pasien dengan persepsi tentang aspek hukum keselamatan pasien yang negatif. Secara statistik mengguna-kan uji Chi-Square terdapat hubungan antara pengetahuan pasien tentang aspek hukum keselamatan pasien dengan partisipasi pasien dalam keselamatan pasien di Instalasi Paviliun Ambun Pagi RSUP DR. M. Djamil Padang $(p=0,007)$.

Tabel 3. Hubungan persepsi pasien tentang aspek hukum keselamatan pasien dengan partisipasi pasien dalam keselamatan pasien di instalasi paviliun Ambun Pagi RSUP Dr. M. Djamil Padang

\begin{tabular}{|c|c|c|c|c|c|c|}
\hline \multirow{3}{*}{$\begin{array}{c}\text { Persepsi } \\
\text { Pasien }\end{array}$} & \multicolumn{5}{|c|}{ Partisipasi Pasien } & \multirow{3}{*}{ p } \\
\hline & \multicolumn{2}{|c|}{ Tinggi } & \multicolumn{2}{|c|}{ Rendah } & Jumlah & \\
\hline & $f$ & $\%$ & $f$ & $\%$ & $\%$ & \\
\hline Positif & 16 & 61,54 & 10 & 38,46 & 26100 & 0,007 \\
\hline Negatif & 13 & 26,53 & 36 & 73,47 & 49100 & \\
\hline
\end{tabular}

\section{PEMBAHASAN}

Masalah hukum seputar keselamatan pasien tidak bisa dan tidak boleh dipisahkan dari tujuan kebijakan kesehatan secara umum. Hak atas keselamatan merupakan titik kunci dalam pelaksanaan hak atas kesehatan. Mewujudkan hak atas kesehatan sangat berkaitan erat dengan hak asasi manusia yang lainnya, termasuk hak atas pangan, perumahan, pekerjaan, pendidikan, non diskriminasi, akses informasi, dan partisipasi. ${ }^{11}$

Partisipasi aktif pasien dalam perawatan mereka sendiri telah diketahui dapat meningkatkan motivasi dan kepatuhan mereka terhadap konsumsi obat-obatan, memberikan hasil pengobatan yang lebih baik, menciptakan kepuasan yang tinggi dengan sikap menerima, serta mengurangi stres dan kecemasan. ${ }^{12}$ Hasil penelitian di Instalasi Paviliun Ambun Pagi
RSUP Dr. M. Djamil Padang menunjukkan bahwa partisipasi pasien dalam keselamatan pasien masih rendah, sebagaimana pada Diagram 3 terlihat sebagian besar $(61,33 \%)$ subyek penelitian memiliki partisipasi yang rendah dalam keselamatan pasien.

Beberapa faktor utama sebagai penghambat bagi pasien untuk berpartisipasi dalam pelayanan kesehatan menurut laporan dari European Commission adalah sikap pasien, kurangnya pengetahuan dan kesadaran pasien dan kurang tersedianya waktu dan dukungan para paraktisi. Sebagian besar pasien di Eropa Timur terhalang oleh kekurangan akses atau tidak ada akses terhadap pelayanan kesehatan dasar dan kekurangan dasar keyakinan dan kepercayaan terhadap dokter dan sistem pelayanan kesehatan mereka. ${ }^{13}$ Beberapa pasien menolak untuk berpartisipasi aktif dalam keselamatan pasien karena mereka merasa bukan perannya, ${ }^{14}$ atau enggan untuk bersikap proaktif dan lebih memilih untuk menyerahkan kepada profesional kesehatan, ${ }^{15}$ atau merasa diri mereka terbatas pada peran pasif dan puas dengan hanya menerima informasi tentang perawatan dan pengobatan. ${ }^{16}$

Pengetahuan hukum pasien, terutama tentang aspek hukum yang berhubungan dengan keselamatan pasien di Instalasi Paviliun Ambun Pagi RSUP Dr. M. Djamil Padang masih rendah. Pengetahuan hukum yang rendah dapat merupakan indikasi kurangnya kesadaran tentang hukum, sebagaimana Soekanto menyatakan bahwa pengetahuan hukum seseorang merupakan indikator pertama dari kesadaran hukum. ${ }^{17}$

Kecenderungan hubungan pengetahuan pasien tentang aspek hukum keselamatan pasien dan partisipasi pasien dalam keselamatan pasien dalam penelitian ini ditunjukkan oleh persentase tertinggi subyek penelitian yang memiliki pengetahuan kurang tentang aspek hukum dalam keselamatan pasien terdapat pada subyek penelitian yang memiliki tingkat partisipasi yang rendah dalam keselamatan pasien. Secara statistik dengan uji Chi-square terbukti bahwa ada hubungan yang signifikan antara pengetahuan pasien tentang aspek hukum keselamatan pasien dengan partisipasi pasien dalam keselamatan pasien di Instalasi Paviliun Ambun Pagi RSUP DR. M. Djamil Padang dengan nilai $p=0,024$. 
Kondisi masih rendahnya pengetahuan hukum akan mengakibatkan ketidakpedulian dan berbagai bentuk pelanggaran terhadap hak, termasuk hak-hak penting yang berhubungan secara langsung atau tidak langsung dengan keselamatan pasien. ${ }^{18}$ WHO mengakui bahwa dibutuhkan pasien dengan pengetahuan, keterampilan dan kepercayaan diri untuk mengelola kesehatan mereka, berpartisipasi dalam perawatan dan menentukan pilihan diagnostik, berkolaborasi dengan penyedia pelayanan kesehatan, memilih penyedia layanan yang berkualitas baik, dan secara lebih umum menavigasi sistem pelayanan kesehatan. ${ }^{9}$

Pengetahuan sangat erat kaitannya dengan pendidikan dimana diharapkan sesorang dengan pendidikan tinggi, maka orang tersebut akan semakin luas pula pengetahuannya. ${ }^{19}$ Seseorang yang memiliki pendidikan rendah tetapi jika ia mendapatkan informasi yang baik dari berbagai media misalnya televisi, radio atau surat kabar, maka hal itu akan dapat meningkatkan pengetahuan seseorang. Kebanyakan pasien memerlukan orientasi dan pendidikan karena kurangnya pengetahuan mereka tentang rutinitas dan prosedur perawatan kesehatan dan cara mendeteksi dan melaporkan perubahan dalam kondisi klinis mereka. ${ }^{20}$

Pasien juga harus berkompeten untuk memahami informasi yang relevan dan keputusan berada di tangan mereka, pasien tidak harus dipaksa menerima pengobatan yang bertentangan dengan keinginan mereka. ${ }^{21}$ Mendidik pasien dengan pengetahuan yang diperlukan untuk perawatan mereka akan mendorong mereka untuk berpartisipasi secara aktif dalam pengambilan keputusan.

Pengetahuan akan melahirkan kepercayaan sehingga pasien akan lebih percaya dengan kemampuannya untuk membuat keputusan ketika diinformasikan dengan baik. $^{22}$ Pasien dengan pengetahuan tentang keselamatan pasien dan familier dengan proses perawatan mereka akan lebih berinisiatif untuk terlibat dalam keselamatan pasien dan mampu memantau dan mendeteksi kesalahan praktik yang berhubungan dengan perawatan mereka sendiri. $^{23}$
Persepsi pasien tentang aspek hukum keselamatan pasien di Instalasi Paviliun Ambun Pagi RSUP Dr. M. Djamil Padang pada penelitian ini terlihat masih kurang baik, dimana sebagian besar subyek penelitian memiliki persepsi yang negatif tentang aspek hukum dalam keselamatan pasien. Kecenderungan hubungan persepsi pasien tentang aspek hukum keselamatan pasien dengan partisipasi pasien dalam keselamatan pasien terlihat bahwa persentase tertinggi subyek penelitian yang memiliki persepsi negatif tentang aspek hukum dalam keselamatan pasien terdapat pada tingkat partisipasi yang rendah dalam keselamatan pasien. Secara statistik dengan uji Chi-square terbukti bahwa ada hubungan yang signifikan antara persepsi pasien tentang aspek hukum keselamatan pasien dan partisipasi pasien dalam keselamatan pasien dengan nilai $p=0,007$.

Faktor yang mempengaruhi persepsi seseorang dapat berupa faktor internal: perasaan, sikap dan kepribadian individu, prasangka, keinginan atau harapan, perhatian (fokus), proses belajar, keadaan fisik, gangguan kejiwaan, nilai dan kebutuhan juga minat, dan motivasi, dan faktor eksternal: latar belakang keluarga, informasi yang diperoleh, pengetahuan dan kebutuhan sekitar, intensitas, ukuran, keberlawanan, pengulangan gerak, hal-hal baru dan ketidakfamiliaran atau keterasingan suatu obyek. ${ }^{24}$ Persepsi negatif menurut Robbins dapat muncul karena adanya ketidakpuasan individu terhadap objek yang menjadi sumber persepsinya, adanya ketidaktahuan individu serta tidak adanya pengalaman individu terhadap objek yang dipersepsikan. ${ }^{25}$ Individu cenderung melihat kepada hal-hal yang mereka anggap akan memuaskan kebutuhan-kebutuhan mereka, dan mengabaikan halhal yang dianggap merugikan/ mengganggu. Rakhmat menambahkan tiga faktor personal yang mempengaruhi persepsi adalah pengalaman, motivasi dan kepribadian. Bahwa seseorang yang telah mempunyai pengalaman tentang hak-hak tertentu akan mempengaruhi kecermatan seseorang dalam memperbaiki persepsi. Semakin seseorang berpengalaman dalam suatu hal semakin baik 
persepsinya. Motivasi individu terhadap suatu informasi akan mempengeruhi persepsinya. Seseorang yang memiliki motivasi dan harapan yang tinggi terhadap sesuatu, cenderung akan memiliki persepsi yang positif terhadap objek tersebut. Kemudian kepribadian dalam psikoanalisis dikenal sebagai proyeksi, yaitu usaha untuk mengeksternalisasi pengalaman subjektif secara tidak sadar. Kepribadian seseorang yang extrovert dan berhati halus cenderung akan memiliki persepsi yang lebih baik terhadap sesuatu. ${ }^{26}$

Keuntungan berpartisipasi bagi pasien dalam menciptakan keselamatan bergantung kepada kesadaran pasien akan kebutuhan mereka untuk terlibat. Pasien akan berkeinginan untuk berpartisipasi, bila menurut persepsi mereka hal ini merupakan hal yang normal dan perilaku dapat diterima, maka dalam mendesain intervensi yang mendorong partisipasi pasien dalam program keselamatan dibutuhkan pengertian tentang keyakinan dan sikap pasien terhadap kesehatan. ${ }^{14}$ Pengalaman pasien dengan kejadian-kejadian yang membahayakan juga akan meningkatkan kewaspadaan dan penilaian kritisnya terhadap kualitas pelayanan. ${ }^{9}$ Bila pasien dapat mempersepsikan bahwa mereka sangat rentan terhadap insiden keselamatan pasien, maka tentunya mereka mau untuk memainkan peranan dalam mengurangi kerentanan mereka akan terjadinya hal tersebut. Namun beberapa penghambat (misalnya: faktor biaya) dapat menjadi sebuah persepsi atau sesuatu yang nyata. Hambatan juga dapat berupa komponen psikologis tentang isu-isu negatif untuk menolak keinginan berpartisipasi, faktor kenyamanan (nilai), dan/ atau faktor penghambat yang nyata seperti kurangnya fasilitas atau pemrograman. ${ }^{22}$ Pasien dengan pengalaman penyakit mereka akan sangat rentan dalam memicu reaksi yang dominan negatif berupa emosional dan kecemasan. Emosi negatif tersebut dapat menyebabkan pasien mengalami peningkatan kerentanan persepsi terhadap peristiwa kehidupannya yang negatif, termasuk insiden keselamatan pasien yang pada gilirannya akan meningkatkan partisipasi pasien untuk berperilaku yang berhubungan dengan keselamatan. ${ }^{27}$
Banyak konflik terjadi karena didasarkan pada kesalahan persepsi. Lemahnya penegakan hukum, rumah sakit yang lebih berorientasi bisnis daripada sebagai lembaga pelayanan masyarakat, moralitas pekerja kesehatan yang begitu rendah dan cara pandang terhadap pasien hanya sebentuk komoditas, dan ketidaktahuan pasien akan haknya merupakan faktor yang menyebabkan terabaikannya hak-hak pasien. Pola hubungan paternalistik antara dokter dengan pasien juga ikut membentuk persepsi dalam pola pemberian pelayanan kesehatan. Pada model ini terdapat suatu anggapan bahwa dokter akan berupaya semaksimal mungkin untuk menyembuhkan pasien, seperti seorang bapak yang baik yang akan berbuat apa saja untuk kepentingan anaknya. Pasien diharapkan akan bertindak sebagai anak yang patuh dan percaya bahwa dokter akan bertindak sebagai bapak yang baik. ${ }^{28}$

Umumnya pada kebanyakan negara yang sedang berkembang, paternalisme masih diterapkan. Dalam model ini juga terdapat suatu persepsi bahwa pasien yang musti berterima kasih atas segala keputusan yang dibuat oleh pemberi pelayanan kesehatan, bahkan terpaksa untuk setuju walaupun masih dalam keraguan. Pasien karena keawamannya atau ketidak-tahuannya hanya menyerahkan masalah atau penyakit yang sedang dialaminya kepada dokter untuk penyembuhan penyakitnya, dan pasien diharapkan patuh menjalankan semua nasihat dari dokter. Bahkan pasien kadang-kadang takut untuk bertanya dan menghentikan pengobatan bila terjadi sesuatu yang tidak dijelaskan sebelumnya. ${ }^{29}$

Keterbatasan dalam penelitian ini adalah tidak semua faktor-faktor yang mempengaruhi partisipasi pasien yang disebutkan di atas dianalisis hubungannya dengan partisipasi pasien dalam keselamatan pasien. Penelitian ini menggunakan metode adalah Cross Sectional Study dengan ruang lingkup penelitian hanya dibatasi atas tiga variabel yang terdiri dari dua variabel bebas, yaitu: pengetahuan dan persepsi pasien tentang aspek hukum keselamatan pasien dan satu variabel terikat, yaitu: partisipasi pasien dalam keselamatan pasien. Kemudian dilakukan analisis terhadap kedua 
hubungan variabel bebas dan variabel terikat untuk mengetahui hubungan pengetahuan dan persepsi pasien dengan partisipasi pasien dalam keselamatan pasien di Instalasi Paviliun Ambun Pagi RSUP DR. M. Djamil Padang.

\section{SIMPULAN}

Hasil penelitian telah membuktikan adanya hubungan antara pengetahuan pasien tentang aspek hukum keselamatan pasien dengan partisipasi pasien dalam keselamatan pasien di Instalasi Paviliun Ambun Pagi RSUP DR. M. Djamil Padang, dan adanya hubungan antara persepsi pasien tentang aspek hukum keselamatan pasien dengan partisipasi pasien dalam keselamatan pasien di Instalasi Paviliun Ambun Pagi RSUP DR. M. Djamil Padang.

\section{SARAN}

Perlu digiatkan upaya-upaya untuk mendidik pasien dan keluarganya tentang kewajiban dan tanggung jawab pasien dalam asuhan pasien sesuai dengan standar Permenkes RI Nomor 1691 tahun 2011, sehingga kriteria keselamatan dalam pemberian pelayanan dapat ditingkatkan dengan keterlibatan pasien yang merupakan partner dalam proses pelayanan. Upaya pemberian informasi dan edukasi bagi pasien dan keluarga untuk peningkatan pengetahuan ini, dan tentunya perlu mempertimbangkan intensitas dan kejelasan dari informasi yang diberikan. Dengan pendidikan tersebut diharapkan pasien dan keluarga dapat:

1. Memberikan informasi yang benar, jelas, lengkap dan jujur.

2. Mengetahui kewajiban dan tanggung jawab pasien dan keluarga.

3. Mengajukan pertanyaan-pertanyaan untuk hal yang tidak dimengerti.

4. Memahami dan menerima konsekuensi pelayanan.

5. Mematuhi instruksi dan menghormati peraturan rumah sakit.

6. Memperlihatkan sikap menghormati dan tenggang rasa.

7. Memenuhi kewajiban finansial yang disepakati.

\section{UCAPAN TERIMA KASIH}

Terima kasih kepada semua yang telah memberikan bimbingan, saran, maupun kritikan, dalam penelitian ini, juga terima kasih kepada semua responden yang telah bersedia berpartisipasi dalam penelitian ini.

\section{DAFTAR PUSTAKA}

1. World Health Organization. Exploring patient participation in reducing health-care-related safety risks. Copenhagen, Denmark: WHO Regional Office for Europe; 2013.

2. Kohn L, Corrigan J, Donaldson M, editor (penyunting). To err is human: building a safer health system. Washington DC: Institute of Medicine Committee on Quality of Health Care in America; 2000.

3. Donaldson SL. Patient safety. World Health Organization; 2015 (diunduh 25 Mei 2015). Tersedia dari: http://www.who.int/ patientsafety/about/en/

4. Vahdat S, Hamzehgardeshi L, Hessam S, Hamzehgardeshi Z. Patient involvement in health care decision making: a review. Iranian Red Crescent Medical Journal. 2013;16(1), e12454.

5. Undang-Undang RI Nomor 44 tahun 2009 tentang Rumah Sakit.

6. Peraturan Menteri Kesehatan RI Nomor 1691/ MENKES/ PER/ VIII/ 2011 tentang Keselamatan Pasien Rumah Sakit

7. Departemen Kesehatan RI. Panduan nasional keselamatan pasien rumah sakit. Depkes Rl; 2008

8. Komite Mutu dan Manajemen Risiko. Laporan insiden keselamatan pasien RSUP Dr. M. Djamil. Padang. RSUP Dr. M.Djamil; 2015.

9. Lemeshow S, Hosmer DW Jr, Klar J, Lwanga SK, Adequacy of Sample size in health studies. USA: WHO; 1990.

10. Singarimbun $M$, Effendi $S$. Metode penelitian survai. Jakarta: Pustaka LP3ES; 2011.

11. World Health Organization. Exploring patient participation in reducing health-care-related safety risks. Copenhagen Denmark: WHO Regional Office for Europe; 2013. 
12. Larsson IE, Sahlsten MJM, Segesten K, Plos KA. "Patients 'perceptions of nurses' behaviour that influence patient participation in nursing care: a critical incident study." Nursing Research and Practice. 2011, Article ID 534060:8.

13. European Commission Eurobarometer Qualitative study. Patient involvement aggregate report. May 2012. TNS Qual+. Coord by DG COMM R\&S unit, Brussels (diunduh 25 Mei 2015). Tersedia dari: http://ec.europa.eu/public opinion/archives/quali/ql 597 patient en.pdf

14. Schwappach DL, Wernli M. Am I (un)safe here? Chemotherapy patients' perspectives towards engaging in their safety. Quality and Safety in Health Care. 2010; 19, e9

15. Rathert C, Huddleston N, Pak Y. Acute care patients discuss the patient role in patient safety. Health Care Management Review. 2011; 36:13444.

16. Flink M, Öhlén G, Hansagi $H$, Barach $P$, Olsson M. Beliefs and experiences can influence patient participation in handover between primary and secondary care-a qualitative study of patient perspectives. BMJ Quality \& Safety; 2012; 21: i76i83.

17. Soekanto S. Keasadaran dan kepatuhan hukum. Jakarta: CV Rajawali; 1980.

18. Tarasenko N, Virone M G. Patient engagement in reducing safety risk in health care. Copenhagen: WHO Regional Office for Europe; 2011.

19. Notoatmodjo S. IImu perilaku kesehatan. Jakarta: Rineka Cipta; 2012.

20. Rainey H, Ehrich K, Mackintosh N, Sandall J., The role of patients and their relatives in 'speaking up' about their own safety - a qualitative study of acute illness. Health Expectations; 2013; DOI: 10.1111/ hex.12044.

21. Small N, Chew-Graham CA, Whalley DW, Protheroe J. Patient empowerment in long-term conditions: development and preliminary testing of a new measure. BMC Health Services Research. 2013; DOI: 10.1186/1472-6963-13-263.

22. Longtin Y, Sax H, Leape LL, Sheridan SE, Donaldson L, Pittet D. Patient participation: current knowledge and applicability to patient safety. Mayo Clinic Proceedings; 2010; 85(1):53-62.

23. Davis RE, Jacklin $R$, Sevdalis $N$, Vincent CA. Patient involvement in patient safety: what factors influence patient participation and engagement? Health Expectations. 2007;10(3):259-67.

24. Toha M. Perilaku organisasi, konsep dasar dan aplikasinya. Jakarta: Raja Grafindo Persada; 2009

25. Robbins SP. Prinsip-Prinsip Perilaku Organisasi. Edisi Ke-5 (terjemahan). Jakarta: Penerbit Erlangga; 2002.

26. Rakhmat J. Psikologi Komunikasi. Bandung: PT. Remaja Rosdakarya; 2004.

27. Galloway RD. Health Promotion: causes, beliefs and measurements. Clinical Medicine and Research. 2004;1(3):249-58.

28. Budiman, Riyanto A. Kapita selekta kuesioner pengetahuan dan sikap dalam penelitian kesehatan. Jakarta: Penerbit Salemba Medika; 2013.

29. Hartono S. Perpustakaan hukum online: BPHN Badan Pembinaan Hukum Nasional; 2009 (diunduh 20 Mei 2015). Tersedia dari: http://perpustakaan.bphn.go.id/index.php/searchkat alog/downloadDatabyld/41215/mhn090203.pdf 